\title{
Accounting
}

\section{Successful adoption of the village's financial system}

\author{
Ni Made Mei Anggrenia ${ }^{*}$, Dodik Ariyanto ${ }^{a}$, Herkulanus Bambang Suprasto ${ }^{a}$ and A.A.N.B \\ Dwirandra ${ }^{a}$
}

${ }^{a}$ Faculty of Economics and Business, Udayana University, Indonesia

\begin{tabular}{l}
\hline C H R O N I C L E \\
\hline Article history: \\
Received May 152020 \\
Received in revised format May \\
162020 \\
Accepted July 62020 \\
Available online \\
July 62020 \\
\hline Keywords: \\
DeLone \& McLean \\
Trust in government \\
Trust in technology \\
Net benefits
\end{tabular}

\section{A B S T R A C T}

This paper aims to test the success of the village financial system (SISKEUDES) using the success model of information System DeLone \& McLean and trust theory. Eight variables verified in research are system quality, information quality, service quality, trust in government organization, trust in technology, usage, user satisfaction and net benefits. The research was conducted by providing questionnaires to users of SISKEUDES SARBAGITA area (Denpasar, Badung, Gianyar and Tabanan) in Bali. Sampling of research samples was based on nonprobability sampling with purposive sampling and hypothesis testing was performed using Partial Least Square. The results of the research show that the quality of information system positively affected the use of SISKEUDES. Quality of information, service quality, trust in government organization, trust in technology did not have any effect on the use of SISKEUDES. The quality of the system, information quality and trust in technology proved to be positively influential on user satisfaction. Service quality and trust in government organization had no effect on user satisfaction but user usage and satisfaction proved to be positively influential on net benefits.

\section{Introduction}

The presence of information technology in the era of globalization and digitization has brought about change and gives much influence on life (Yuhelson, et.al., 2020). The development of information technology is expected to provide benefits to improve individual performance (DeLone \& McLean, 1992; Hou, 2012) and later organization impact (DeLone \& McLean, 2003). Adoption and utilization of information systems is an emerging behavior due to the advantages of the use of information systems based on information and communication Technology (ICT) (Seddon, 1997; Navarro-Galera et al., 2016). Information and communication technology (ICT) is not only utilized by the economic and business sectors (Ariyanto, et al., 2014), but also utilized by the government sector (Yuhelson et al., 2020; Navarro-Galera et al., 2016; Rimawati, 2012). Government agencies utilize the development of information technology to support the creation of good governance through e-government (Paquette, Jaeger, \& Wilson, 2010; Navarro-Galera et al., 2016). In Indonesia there is a government policy on regional autonomy that causes the delegation of authority from the central government to the local government (Kristiansen et al., 2009). The financial management of local governments is required to utilize the information system in order to produce transparent, accountable, and free of abuse financial statements (Paquette et al., 2010; Manoharan \& Ingrams, 2018). Development in Indonesia (UU No.6, 2014) starts from the suburbs areas and villages. The village government is part of the district government or the city that has the function as the smallest form of government in the territory of the Republic of Indonesia (UU No.6, 2014). The village

* Corresponding author.

E-mail address: mei.anggreni@yahoo.com (N. M. M. Anggreni) 
becomes the spearhead in every development and community implementation in the area. Therefore, the village government is prepared to respond to the process of modernization, globalization and the evolving democratization without losing its identity in accordance with the regulated law (UU No.6, 2014). which is defined by Government Regulation (PP No.11, 2019).

The birth of the law (UU No.6, 2014) about the village apparently raises the pros and cons of various parties (Widagdo et al., 2016). The existence of the law is feared to ensnare the village apparatus in the Gulf of corruption (Wiyanto, 2014; Nam, 2018). However, the law was made so that the village government was more independent in managing the government, finance, and wealth of the village in the form of the village's income and expenditure budget (APBDes). The APBDes are quite fantastic and varied because the value is approaching the number one billion rupiah per village. APBDes will be more than one billion depending on village conditions and year-on-year upgrade (Kementrian Keuangan Republik Indonesia, 2017). The management of large village funds must be supported with accounting information system to ensure accountability of village funds (Navarro-Galera et al., 2016). Village financial System (SISKEUDES) is an application developed by the Financial Supervisory and Development Agency (BPKP) in order to improve the quality of the village's financial governance. However, the competence of village apparatus in the administration, reporting, and financial accountability of the village is not adequate (BPKP, 2015). SISKEUDES is expected to be a solution of village funds accountability and able to help financial management effectively, efficiently and integrated in accordance with statutory regulations (BPKP, 2015; Manoharan \& Ingrams, 2018; Brandon, 2013). The features in the village's financial management application are made as simple as possible to facilitate the user (Davis, 1986; Rimawati, 2012; Halawi et al., 2007) in operating the SISKEUDES application.

SISKEUDES Program is dedicated to all Indonesian village governments. In the province of Bali, SISKEUDES has begun to be introduced in 2016 and started to be implemented by all districts/cities in Bali in 2017 (BPKP, 2015). The research focuses on evaluating the success of SISKEUDES implementation in the village government in Bali, especially in the region SARBAGITA (Denpasar, Badung, Gianyar, Tabanan) in Bali (Rahyuda et al., 2019). The application of SISKEUDES in the region of SARBAGITA is expected to be done optimally, because SARBAGITA is a national strategic area that region and the space prioritized because it has a very important influence nationally to the defense and security of the country, economy, social and culture. The success of accounting information system in an organization depends on how the system is run, the ease of use of the system used by the wearer and the technology distribution according to the task (Goodhue et al., 1995; Petter at al., 2013). The research seeks to explore deeply about the success factors of information systems using models (DeLone \& McLean, 2003; Petter et al., 2013) consisting of six variables, namely system quality, information quality, service, usage, user satisfaction, and net benefits. It then adds a dimension to the belief theory of (DeLone \& McLean, 2003; Petter et al., 2013), namely trust in government organizations and trust in technology. The information system is researched, evaluation and assessment about the success of the application of SISKEUDES in SARBAGITA as a strategic area of national development in Bali (Rahyuda et al., 2019).

\section{Literature review}

The theory of reasoned action (TRA) was proposed by Icek Ajzen and Martin Fishbein in 1980. The theory of reasoned action (Ajzen, 1989) assumes the intention of behavior determined by two factors, namely attitude toward behavior and subjective norm. Then TRA was developed into (TAM) Technology Acceptance Model (Davis, 1986) and performed testing by comparing TRA and TAM (Davis et al., 1989). TRA and TAM in the context of this research explains the intention behavior to use SISKEUDES system influenced by attitude toward behavior and subjective norm. Meanwhile, attitude toward behavior is influenced by perceived usefulness and perceived ease of use (Davis, 1986; Davis et al., 1989). Size success of SIKEUDES adoption can be seen from use, user satisfaction, individual impact, impact organization (DeLone \& McLean, 1992) and net and benefit (DeLone \& McLean, 2003; Petter et al., 2013). Trust (Mayer et al., 1995) is a willingness to trust the other party based on the expectation that the other party will take a certain action for the party to believe it. Trust is necessary for the user of the new information system so that he feels new information system technology can improve individual performance (DeLone \& McLean, 1992) in running activities in the organization impact (DeLone \& McLean, 2003). The trust of e-government is related to the security and privacy assurance that the Government has provided to the organization or society as a user (Deakins \& Dillon, 2002). The trust of the e-Government service is constructed from several dimensions. Srivastava and Teo (2005); Chen et al. (2015) states that the dimension of confidence in e-government is divided into two, namely (1) the Trust in government organization includes the trust of the community and the village device to the government's ability and trust in the Government's willingness to use and development of the e-government services. Trust in government organizations is built by conducting measures to build the trust of the village and community devices to government institutions, to obtain the commitment and consistency of village government organizers and support the implementation and development of e-government. (2) This trust in technology includes the trust of the community and the village device to the technology used in government institutions. This Trust in technology is built by proactively providing counseling on technology-related knowledge and skills, a legal umbrella that protects the security and privacy of information when using an information technology. Quality system means the quality of the combination of hardware and software in information systems (DeLone \& McLean, 1992; DeLone \& McLean, 2003; Petter et al., 2013). Results of the study by Tan et al., (2015) and (Alsabawyet al., 2016) became empirical evidence that the 
quality of the system would affect system usage and user satisfaction. The quality of the system affects the use and satisfaction of the user's online tax filling system (Chen et al., 2015; Kofahe et al., 2019; Al-Kofahi, 2020) And the use of e-learning systems (Mohammadi, 2015; Seta et al., 2018). The results of the overall research show the better the quality that has been, the increased system usage and user satisfaction. Thus, the hypothesis is formulated:

$\mathrm{H}_{1}$ : System quality has a positive effect on system usage.

$\mathrm{H}_{2}$ : System quality affects positively on user satisfaction.

The good of information quality is represented by the usefulness of the output generated by a system (DeLone \& McLean, 1992; DeLone \& McLean, 2003). The usefulness of the output of a system can affect the system usage (Petter et al., 2013). Research conducted by Sumiyana and Pribadi (2010), Wahyuni (2011), Halawi, et al. (2007) dan Rai, et al. (2002) found that the information quality affects the use and satisfaction of online user tax filling (Chen et al., 2015; Kofahe et al., 2019; AlKofahi, 2020) and the use of e-learning system (Mohammadi, 2015; Seta et al., 2018). The results showed that if the user feels the quality of information produced by a system provides benefits to the user, the user will increase the use of a system. Conversely, if the quality of the information generated by a system is felt not to provide benefits or not quality, then the user tends to decrease or reduce the use of the system and user satisfaction. Research hypothesis, that is.

$\mathrm{H}_{3}$ : Information quality positively affects system usage.

$\mathrm{H}_{4}$ : Information quality positively affects user satisfaction.

The quality of service affects system usage (DeLone \& McLean, 2003). The quality of services owned by a system affects the use and satisfaction of the user system (Rimawati, 2012; Sumiyana \& Pribadi, 2010), the use of online tax filling (Chen et al., 2015; Kofahe et al., 2019; Al-Kofahi, 2020), the use of e-learning system (Mohammadi, 2015; Seta et al., 2018) and patient acceptance of health information technology (Ahlan \& Ahmad, 2015). So, if the service is owned by the system has good quality, it affects the increased use of the system and user satisfaction. Thus, it is formulated:

$\mathrm{H}_{5}$ : Service quality has a positive effect on system usage.

$\mathrm{H}_{6}$ : Service quality has a positive effect on user satisfaction.

Trust in government organizations is built by enhancing measures of the use of information systems, and the commitment and consistency of government and local governments to support the implementation, use and development of the system. The higher the trust in government agencies the higher the use of the system. Results of the study (Chen et al., 2015; Grimmelikhuijsen at al., 2013; Kofahe et al., 2019; Al-Kofahi, 2020); Xiao at al. (2018) stated that trust in the government is a factor that affects the interest of use and satisfaction of information system users. Research results (Ahlan \& Ahmad, 2015; Porumbescu, 2016) state the factors that affect the interest to use and user satisfaction of the system is trust. Thus, the hypothesis is:

$\mathrm{H}_{7}$ : Trust in government organization has positive effect on system usage.

$\mathrm{H}_{8}$ : Trust in government organization has a positive effect on user satisfaction.

Trust in this technology includes community confidence in the technology used in government agencies. The higher the individual confidence in the technology, the more the use of the system provided by the government. Research results (Rakhmawati \& Isharijadi, 2013; Grimmelikhuijsen at al., 2013); (Xiao et al., 2018) and research (Saputro \& Sukirno, 2013) states that the factors affecting the interest to use the system are belief (Chen et al., 2015). Thus the fifth hypothesis that can be formulated is as follows:

$\mathrm{H}_{9}$ : Trust in technology positively affects system usage.

$\mathrm{H}_{10}$ : Trust in technology positively affects user satisfaction.

The use of high information systems, can provide benefits to the organization (Petter et al., 2013). This is because with the benefit of a system well by individuals, it will help in completing the work that exists. The impact is that it can drive the high productivity of an individual (DeLone \& McLean, 1992) which ultimately improves the organizational performance (DeLone $\&$ McLean, 1992). Successful use of the system will be beneficial in improving the performance of individuals and organizations and will bring benefits to the organization (Petter et al., 2013). Many studies (Chen et al., 2015; Kofahe et al., 2019; Al-Kofahi, 2020) demonstrate the use of the system and user satisfaction effect on the net benefits of online tax filling, and the net benefit of e-Learning (Mohammadi, 2015). Thus, the hypothesis can be formulated namely:

H11: System usage positively affects the net benefits.

H12: User satisfaction positively affects the net benefits. 


\section{Methodology/materials}

Research is conducted in the province of Bali in the region SARBAGITA (Denpasar, Badung, Gianyar, Tabanan) because SARBAGITA is a national strategic area (Rahyuda et al., 2019). The region and the space arrangement are prioritized because they have a very important national influence on State sovereignty, defense and security of the country, economic, social, cultural and/or environmental, including world heritage-designated territories.

\section{Table 1}

Research Construct

\begin{tabular}{|c|c|c|}
\hline Construct & Indicator & Source \\
\hline $\begin{array}{l}\text { System Information Quality } \\
\text { (SIQ) }\end{array}$ & $\begin{array}{l}\text { 1. Ease of Use } \\
\text { 2. Speed } \\
\text { 3. Flexsibility }\end{array}$ & $\begin{array}{l}\text { Davis et al., 1989; DeLone \& McLean, 2003; Teo et al., 2008; } \\
\text { Petter et al., 2013; Chen et al., } 2015 .\end{array}$ \\
\hline Information Quality (IQ) & $\begin{array}{l}\text { 1. Relevancy } \\
\text { 2. Accuracy } \\
\text { 3. Timeliness } \\
\text { 4. Reliability }\end{array}$ & $\begin{array}{l}\text { DeLone \& McLean, 2003; Teo et al., 2008; Petter et al., 2013; } \\
\text { Chen et al., } 2015\end{array}$ \\
\hline Service Quality (SQ) & $\begin{array}{l}\text { 1. Tangibles } \\
\text { 2. Reliability } \\
\text { 3. Responsiveness } \\
\text { 4. Assurance } \\
\text { 5. Empathy }\end{array}$ & $\begin{array}{l}\text { DeLone \& McLean, 2003; Teo et al., 2008; Petter et al., 2013; } \\
\text { Chen et al., } 2015 .\end{array}$ \\
\hline $\begin{array}{l}\text { Trust In Government } \\
\text { (TIG) }\end{array}$ & $\begin{array}{l}\text { 1. Actions } \\
\text { 2. Reliable } \\
\text { 3. Competent } \\
\text { 4. Reliable }\end{array}$ & $\begin{array}{l}\text { Mayer et al., 1995; Teo et al., 2008; Bélanger \& Carter, 2008; } \\
\text { Teo et al., 2008; Wang \& Benbasat, 2008; Chen et al., } 2015 .\end{array}$ \\
\hline $\begin{array}{l}\text { Trust In Technology } \\
\text { (TIT) }\end{array}$ & $\begin{array}{l}\text { 1. Convenience } \\
\text { 2. Protection of } \\
\text { 3. Safe } \\
\text { 4. Trusted }\end{array}$ & $\begin{array}{l}\text { Mayer et al., 1995; Teo et al., 2008; Bélanger \& Carter, 2008; } \\
\text { Teo et al., 2008; Wang \& Benbasat, 2008; Chen et al., } 2015\end{array}$ \\
\hline Use (U) & $\begin{array}{l}\text { 1. Daily used time } \\
\text { 2. Frequency of use }\end{array}$ & DeLone \& McLean, 2003; McGill, et al. 2003. \\
\hline $\begin{array}{l}\text { User Satisfaction } \\
\text { (US) }\end{array}$ & $\begin{array}{l}\text { 1. Completeness of contents } \\
\text { 2. Accuracy } \\
\text { 3. The display } \\
\text { 4. Ease of Use } \\
\text { 5. Timeliness }\end{array}$ & Doll and Torkzadeh, 1988; DeLone \& McLean, 2003. \\
\hline $\begin{array}{l}\text { Net Benefit } \\
(\mathrm{NB})\end{array}$ & $\begin{array}{l}\text { 1. Speed of accomplishing task } \\
\text { 2. Job performace } \\
\text { 3. Effectiviness } \\
\text { 4. Easy of job } \\
\text { 5. Usefulness in work }\end{array}$ & $\begin{array}{l}\text { Davis et al., } 1989 \text {; DeLone \& McLean, 2003; Petter et al., } \\
\text { 2013; Chen et al., } 2015 .\end{array}$ \\
\hline
\end{tabular}

Sampling of research uses nonprobability sampling technique with sampling purposive, i.e. sampling technique with certain consideration (Sugiyono, 2017:144). The criteria in sampling, SISKEUDES users in the village, i.e. the village secretary, head of financial affairs and operator SISKEUDES. Other criteria in determining the sample of this research, namely the village in the area SARBAGITA (Rahyuda et al., 2019) and located in the subdistrict that received the largest village funds in the year 2019. The questionnaire was distributed to thirty six (36) villages in the SARBAGITA area with a total of one hundred and eight (108) respondents. The endogenous variables in this study are system usage, user satisfaction, and net benefits. The exogenous variables in this study are system quality, information quality, service quality, trust in government organization and trust in technology. The construction and research questions are presented in Table 1.

Hypothesis testing using PLS (Partial Least Square) is a structural analysis (SEM) based variance. The research uses a recursive structural model that is a one-way cause model and no reverse direction and no causal influence. So that problems un-identified or over-Domain Keys identified also will not occur. Analysis using PLS carried out three testing stages, namely the outer model analysis, inner model analysis and hypothesis testing.

\section{Results and findings}

\subsection{Measurement model evaluation (outer model)}

Outer model defines the influence between the latent variables with indicators or the outer models define how each indicator relates to its laten variables. Outer model is assessed by testing three stages, namely convergent validity, linear validity and composite reliability. The evaluation of the outer model is done using the PLS Algorithm calculation. The outer model evaluation result is shown in Fig. 1. 


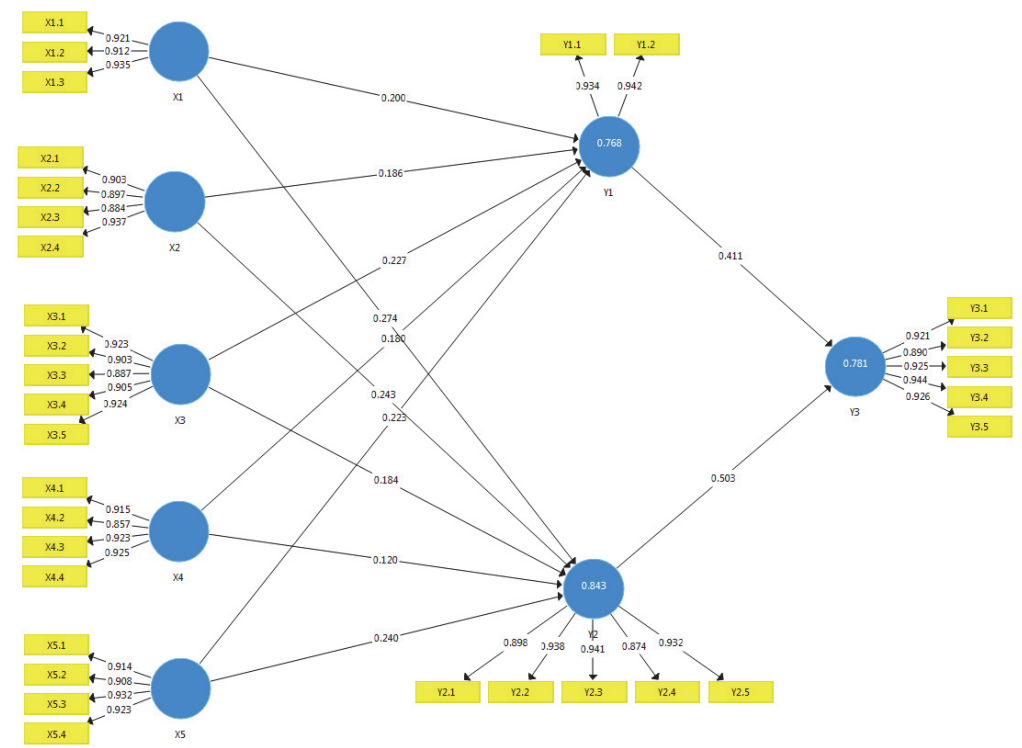

Fig. 1. Outer Model

Convergent validity with reflective indicator can be seen from the correlation between the indicator score and the variable score. Individual indicators are considered reliable when they have a correlation value above 0.50 . The correlation between dimensions and variables in this study can be seen in Table 2. Table 2 shows the entire value of the outer loading indicator has a value above 0.50 . So it can be concluded that the results meet the requirements convergent validity.

Table 2

Outer Model Evaluation Result

\begin{tabular}{|c|c|c|c|c|c|}
\hline Construct & Items & Outer Loading & AVE & Composite Reliability & Cronbach's $\alpha$ \\
\hline \multirow{3}{*}{$\begin{array}{l}\text { System Information Quality } \\
\text { (SIQ) }\end{array}$} & SIQ1 & 0.921 & \multirow{3}{*}{0.820} & \multirow{3}{*}{0.945} & \multirow{3}{*}{0.913} \\
\hline & SIQ2 & 0.912 & & & \\
\hline & SIQ3 & 0.935 & & & \\
\hline \multirow{4}{*}{ Information Quality (IQ) } & IQ1 & 0.903 & \multirow{4}{*}{0.849} & \multirow{4}{*}{0.948} & \multirow{4}{*}{0.927} \\
\hline & IQ2 & 0.897 & & & \\
\hline & IQ3 & 0.884 & & & \\
\hline & IQ4 & 0.937 & & & \\
\hline \multirow{5}{*}{ Service Quality (SQ) } & SQ1 & 0.923 & \multirow{5}{*}{0.851} & \multirow{5}{*}{0.959} & \multirow{5}{*}{0.947} \\
\hline & SQ2 & 0.903 & & & \\
\hline & SQ3 & 0.887 & & & \\
\hline & SQ4 & 0.905 & & & \\
\hline & SQ5 & 0.924 & & & \\
\hline \multirow{4}{*}{ Trust In Government (TIG) } & TIG1 & 0.915 & \multirow{4}{*}{0.826} & \multirow{4}{*}{0.948} & \multirow{4}{*}{0.927} \\
\hline & TIG2 & 0.857 & & & \\
\hline & TIG3 & 0.923 & & & \\
\hline & TIG4 & 0.925 & & & \\
\hline \multirow{4}{*}{ Trust in technology (TIT) } & TIT1 & 0.914 & \multirow{4}{*}{0.820} & \multirow{4}{*}{0.956} & \multirow{4}{*}{0.939} \\
\hline & TIT2 & 0.908 & & & \\
\hline & TIT3 & 0.932 & & & \\
\hline & TIT4 & 0.923 & & & \\
\hline \multirow{2}{*}{ Use (U) } & U1 & 0.934 & \multirow{2}{*}{0.845} & \multirow{2}{*}{0.936} & \multirow{2}{*}{0.864} \\
\hline & $\mathrm{U} 2$ & 0.942 & & & \\
\hline \multirow{5}{*}{ User Satisfaction (US) } & US1 & 0.898 & \multirow{5}{*}{0.880} & \multirow{5}{*}{0.963} & \multirow{5}{*}{0.952} \\
\hline & US2 & 0.938 & & & \\
\hline & US3 & 0.941 & & & \\
\hline & US4 & 0.874 & & & \\
\hline & US5 & 0.932 & & & \\
\hline \multirow{5}{*}{ Net benefits (NB) } & NB1 & 0.921 & \multirow{5}{*}{0.841} & & \\
\hline & NB2 & 0.890 & & & \\
\hline & NB3 & 0.925 & & 0.966 & 0.956 \\
\hline & NB4 & 0.944 & & & \\
\hline & NB5 & 0.926 & & & \\
\hline
\end{tabular}

Source: Processed primary Data, 2020. 
Another method for judging the discriminant validity is by comparing the square root of the Average Variance Extracted ( $\sqrt{ }$ AVE) to each variable with the correlation between variables with other variables in the model. The model has a sufficient validity linear if the AVE squared root for each variable is greater than the correlation between variables and other variables in the model. Testing linear validity can be viewed by assessing the validity of variables at the AVE value. The Model is said to be good if the AVE of each of the variable values is greater than 0.50. The output result in Table 2 indicates that the AVE value of the entire variable is greater than 0.50 so that the model can be said to be valid. Reliability test is done by two criteria, namely composite reliability and Cronbach's Alpha. Variable declared reliable if the composite reliability or Cronbach's alpha value above 0.70 . Output in table 2 shows that composite reliability as well as Cronbach's alpha throughout the research variables are all above 0.70 . Thus, it can be said that the whole variable is reliable.

\subsection{Structural model evaluation (inner model)}

Hypothesis testing can be seen from the T-statistical value and the probability value calculated using the bootstrapping calculation. The bootstrapping analysis results can be seen in Table 3.

Tabel 3

Direct Effects Test Results

\begin{tabular}{|c|c|c|c|c|c|}
\hline No. & $\begin{array}{l}\text { Relationships between } \\
\text { variables }\end{array}$ & $\begin{array}{l}\text { Path coefficient } \\
\text { (Bootstrapping) }\end{array}$ & T Statistic & $\begin{array}{c}\mathrm{P} \\
\text { Value } \\
\end{array}$ & Description \\
\hline $\begin{array}{l}1 \\
2\end{array}$ & $\begin{array}{l}\mathrm{SIQ} \rightarrow \mathrm{U} \\
\mathrm{SIQ} \rightarrow \mathrm{US}\end{array}$ & $\begin{array}{l}0.200 \\
0.274\end{array}$ & $\begin{array}{l}2.017 \\
2.639\end{array}$ & $\begin{array}{l}0.044 \\
0.009\end{array}$ & $\begin{array}{l}\text { Significant } \\
\text { Significant }\end{array}$ \\
\hline $\begin{array}{l}3 \\
4\end{array}$ & $\begin{array}{l}\mathrm{IQ} \rightarrow \mathrm{U} \\
\mathrm{IQ} \rightarrow \mathrm{US}\end{array}$ & $\begin{array}{l}0.186 \\
0.243\end{array}$ & $\begin{array}{l}1.549 \\
2.794\end{array}$ & $\begin{array}{l}0.122 \\
0.005\end{array}$ & $\begin{array}{l}\text { Not Significant } \\
\text { Significant }\end{array}$ \\
\hline $\begin{array}{l}5 \\
6\end{array}$ & $\begin{array}{l}\mathrm{SQ} \rightarrow \mathrm{U} \\
\mathrm{SQ} \rightarrow \mathrm{US}\end{array}$ & $\begin{array}{l}0.227 \\
0.184\end{array}$ & $\begin{array}{l}1.567 \\
1.541\end{array}$ & $\begin{array}{l}0.118 \\
0.124\end{array}$ & $\begin{array}{l}\text { Not Significant } \\
\text { Not Significant }\end{array}$ \\
\hline $\begin{array}{l}7 \\
8\end{array}$ & $\begin{array}{l}\mathrm{TIG} \rightarrow \mathrm{U} \\
\mathrm{TIG} \rightarrow \mathrm{US}\end{array}$ & $\begin{array}{l}0.180 \\
0.120\end{array}$ & $\begin{array}{l}1.834 \\
1.579\end{array}$ & $\begin{array}{l}0.067 \\
0.115\end{array}$ & $\begin{array}{l}\text { Not Significant } \\
\text { Not Significant }\end{array}$ \\
\hline $\begin{array}{c}9 \\
10\end{array}$ & $\begin{array}{l}\mathrm{TIT} \rightarrow \mathrm{U} \\
\mathrm{TIT} \rightarrow \mathrm{US}\end{array}$ & $\begin{array}{l}0.223 \\
0.240\end{array}$ & $\begin{array}{l}1.587 \\
2.035\end{array}$ & $\begin{array}{l}0.113 \\
0.042\end{array}$ & $\begin{array}{l}\text { Not Significant } \\
\text { Significant }\end{array}$ \\
\hline 11 & $\mathrm{U} \rightarrow \mathrm{NB}$ & 0.411 & 3.270 & 0.001 & Significant \\
\hline 12 & $\mathrm{US} \rightarrow \mathrm{NB}$ & 0.503 & 3.918 & 0.000 & Significant \\
\hline
\end{tabular}

Source: Processed primary Data, 2020

Hypotheses are accepted when $\mathrm{P}$ values are $<0.05$ and $\mathrm{T}$ statistic $>1.96$. The results of this research show that the system information quality (SIQ) proved to be positive and significant effect on the SISKEUDES usage (U). The information quality (IQ), Service Quality (SQ), trust in government organization (TIG), trust in technology (TIT) have no significant effect on the SISKEUDES usage (U). The system information quality (SIQ), information quality (IQ) and trust in technology (TIT) proved to be positively and significantly impactful in user satisfaction (US). Service quality (SQ) and trust in government organization (TIG) have no significant effect on user satisfaction (US). The usage system (U) and user satisfaction (US) proved to be a positive and significant effect on the net benefits (NB).

\subsection{Discussion}

The systems information quality (SIQ) proved to be positive and significant in the SISKEUDES usage (U). The results obtained can be interpreted that the higher systems information quality available, then the use of SISKEUDES will be increased. SISKEUDES has fulfilled the expectations of its users by providing flexibility of ease of use, and reliability of the system, to meet the expectations of system users in supporting the operational activities of the village government. The results of this study are in line with the research of Tan et al. (2015); Seta et al., 2018; Wahyuni (2011), as well as Sumiyana and Pribadi (2010); Kofahe et al. (2019) and Al-Kofahi (2020), who found empirical evidence that systems information quality would significantly affect the system usage. System information quality (SIQ) proved to be positively and significantly impactful in user satisfaction (US). The results obtained can be interpreted that higher quality information systems available will increase the satisfaction of SISKEUDES users. The perception of SISKEUDES users in the village government of SARBAGITA region states that easy to use has functions that suit the needs of the user. Users of SISKEUDES can also be said to have been satisfied with the quality of SISKEUDES. The user satisfaction of information systems has the effect of increasing usage in using information systems and supporting the financial management activities (Emawati at al., 2019; Kofahe et al., 2019; Al-Kofahi, 2020). The results of this study are in line with research (Wartini \& Yasa, 2016; Putrawan at al., 2017; Seta et al., 2018; Setyo \& Rahmawati, 2015; Arifin \& Pratolo, 2012). The information quality (IQ) has no significant effect on the SISKEUDES usage (U). The results obtained can be interpreted that the low quality of information cannot affect the level of use SISKEUDES. This is because SISKEUDES users in the village government of SARBAGITA region only use the output/information as a claim or work routine. The information generated by SISKEUDES, is not a determinant of the use of the system, because SISKEUDES will 
still be used to assist in managing the finances of the village. These findings were supported by research conducted by Susanty (2013), McGill et al. (2003), Iivari (2005) and Purwanto (2007). The information quality (IQ) has significant effect on user satisfaction. The results obtained can be interpreted that higher the quality of information will increase the user satisfaction SISKEUDES. The use of SISKEUDES in the village government of SARBAGITA region has made easier and faster village government in the preparation, administration and reporting/financial liabilities, this is evidenced by the high value of the mean in the questionnaire stating that SISKEUDES can provide information in a timely manner. The high quality of the information generated by a system can have a positive impact on the perceived satisfaction of users of the system, because the information generated from the system becomes a solution in order to improve financial management accountability (Emawati at al., 2019; Kofahe et al., 2019; Al-Kofahi, 2020). The results were in line with the research (Istianingsih \& Utami, 2009; Seddon \& Kiew, 1996; Seta et al., 2018; Rai et al., 2002).

Service quality (SQ) has no significant effect on the SISKEUDES usage (U). The results obtained can be interpreted that the low quality of service cannot affect the level of use SISKEUDES. This can be caused by the security guarantee owned by SISKEUDES is not good enough. This can be proved from the results of a questionnaire that shows a security indicator of a safe sense of access to the SISKEUDES has the lowest mean value. SISKEUDES usage to be less capable of providing assurance and security in terms of accessing and submitting financial data. So, it caused the absence of influence between the quality of service on the use of SISKEUDES in the village government in the area SARBAGITA. Similar results were obtained in the research conducted by Tan et al. (2015) and Muharor at al. (2016). Service quality (SQ) has no significant effect on user satisfaction (US). The results can be interpreted that the low quality of service cannot affect the level of user satisfaction SISKEUDES. The findings are supported by the results of research conducted by Tan et al. (2015) and Iranto (2012). Both researchers also found that the quality of service owned by a system does not affect user satisfaction. As with the quality of service that SISKEUDES has, it is not able to affect user satisfaction in the village government of SARBAGITA region. This result is reinforced by a questionnaire answer that shows a security-sense assurance indicator of the access to SISKEUDES has the lowest mean value. SISKEUDES used to be less capable of providing assurance and security in terms of accessing and transmitting data. The trust in government (TIG) organization in this research has no significant effect on the SISKEUDES usage (U). The results obtained can be interpreted that the high low level of user trust SISKEUDES in government organizations, then cannot affect the level of SISKEUDES usage. This is because the village government is required to be able to implement SISKEUDES in government operational activities, manage the village finances and produce a report that can be accounted for (BPKP, 2015). It can be said that the application of SISKEUDES is mandatory so that the level of use of this system is not influenced by the level of trust in government organizations. The results of this research in line with other research (Rimawati, $2012 \mathrm{~b}$ ) proved that belief in the institution has no effect on the use in the success of e-government.

Trust in government (TIG) organizations has no significant effect on the user satisfaction (US). The results obtained can be interpreted that the low level of user trust SISKEUDES in government organizations, it cannot affect the level of satisfaction of SISKEUDES users. User satisfaction can also be fulfilled through the suitability of user perception of information systems. Such perception can be formed by the level of knowledge and experience in using the system, as well as the user's need for information availability. There is a limited information in handling the problems faced by users in using SISKEUDES in the village government of SARBAGITA region to the government above or local governments. This led to the absence of influence between the trust in government organization in the satisfaction of SISKEUDES users. Financial and Development Supervisory Agency (BPKP) and mandatory (Venkatesh et al., 2003) in the village. Trust in technology (TIT) has no significant effect on the SISKEUDES usage (U). The results obtained can be interpreted that the high low level of user trust SISKEUDES on technology, it cannot affect the level of use. Users of SISKEUDES feel the legal structure of the system yet to protect against the problems seen from the results of a questionnaire that shows an indicator of believing in the legal structure and technology can protect the user from having problems with the lowest mean value, so that the level of user trust in technology cannot affect the level of use SISKEUDES. Siskeudes (BPKP, 2015) is an application developed by the Financial and Development Supervisory Agency (BPKP) and mandatory in the village (Venkatesh et al., 2003).

Trust in technology (TIT) has significant effect on user satisfaction (US). The results obtained can be interpreted that the high or low level of user trust SISKEUDES on technology can change the satisfaction of SISKEUDES users. This Trust in technology is built by proactively providing counseling on knowledge and skills related to technology to users of the system (Chen et al., 2015). Users of SISKEUDES in the village government of SARBAGITA region believe that today's technology has a strong environment, it can be seen at a high mean value that indicates that SISKEUDES is a trusted system to be used and able to assist in completing the work, hence the belief in the tenology can improve the satisfaction of SISKEUDES users. The results of this research are in line with Latifah et al. (2020) who also showed that belief is a factor that affects user satisfaction in using ecommerce. The system usage (U) proved to be positive and significant on net benefits (NB). The results obtained can be interpreted that the higher the level of use SISKEUDES will increase the net benefit that SISKEUDES users feel. The more often users use the information system, the more levels of learning on individual performance in the organization, and decisionmaking (McGill et al., 2003; Kofahe et al., 2019; Al-Kofahi, 2020). Positively the existence of information systems will be a stimuli and challenge for individuals in the organization to work better, which in turn impacts the organizational performance. The use of high information systems in the village government of SARBAGITA region can provide benefits to the organization. 
This research is in line with other researches (Noviyanti, 2017; Krisbiantoro., 2015). User satisfaction (US) proved to be positively and significantly influential on the net benefit (NB). The results obtained can be interpreted that the higher the level of user satisfaction in using SISKEUDES, the higher the net benefit that SISKEUDES users feel. SISKEUDES user satisfaction provides the net benefits that have been felt by the user of the system, such as being able to finish the job more quickly and efficiently, as well as improving performance in managing the regional finances. SISKEUDES makes it easy for users to complete their work in a timely manner. The results of this research are in line with the other studies (Noviyanti, 2017; Kofahe et al., 2019; Al-Kofahi, 2020; Kodarisman \& Nugroho, 2013) which shows that the user satisfaction is positively and significantly influential on the net benefits.

\section{Conclusions and recommendations}

Based on the results of research and discussion it can be concluded that the system quality had positive and significant effect on the SISKEUDES usage. Information Quality, service quality, trust in government, trust in technology had no significant effect on the SISKEUDES usage. System quality, information quality and trust in technology proved to be positive and significant in user satisfaction. Service quality and trust in government had no significant effect on user satisfaction. System usage and satisfaction proved to be positively and significantly influential on net benefits. Model testing (DeLone \& McLean, 2003) by augmenting the dimensions of the trust theory had weak effect on quality information, system quality, and service quality, trust in government and trust in technology was a good predictor of system usage variables and user satisfaction in an entity with mandatory system implementations. So for researchers further advised to test Model (DeLone \& McLean, 2003) by increasing the dimension of this belief theory in an entity whose system implementation is still voluntary. The success of the system is not only determined by the technical factors of the system but also by the human psychology factor. Psychological factors can be added to the model (DeLone \& McLean, 2003) to evaluate the application of a system. The theory of Information technology acceptance (Unified Theory of Acceptance and Use of Technology) from Venkatesh et al. (2003) can be used to measure the successful implementation of information technology in terms of its human factors.

\section{References}

Ahlan, A. R., \& Ahmad, B. I. E. (2015). An overview of patient acceptance of health information technology in developing countries: A review and conceptual model. International Journal of Information Systems and Project Management, 3(1), $29-48$.

Ajzen, I. (1989). Attitude Assessment (TRA). In University of Massachusetts-Amherst(pp.1-15).

Al-Kofahi, M. K. (2020). Information Systems Success Model: A Review of Literature. International Journal of Innovation, Creativity and Change.

Alsabawy, A. Y., Cater-Steel, A., \& Soar, J. (2016). Determinants of Perceived Usefulness of e-learning Systems. Computers in Human Behavior, 64, 843-858.

Arifin, J. F., \& Pratolo, S. (2015). Pengaruh kualitas sistem informasi keuangan daerah terhadap kepuasan aparatur pemerintah daerah menggunakan model delone dan mclean. Journal of Accounting and Investment, 13(1), 28-34.

Ariyanto, D., Subroto, B., Purnomosidhi, B., \& Rosidi. (2014). Does the Balinese Tri Hita Karana Culture Affect the Adoption and Usage of Information Technology Systems? Information and Knowledge Management, 4(9), 1-18.

Bélanger, F., \& Carter, L. (2008). Trust and risk in e-government adoption. Journal of Strategic Information Systems, 17(2), $165-176$.

BPKP. (2015). Badan Pengawas Keuangan \& Pembanguan. Aplikasis Sistem Keuangan Desa (SISKEUDES).

Brandon, J. R. (2013). Whistle-blowing (Edition I). Massachusetts: Cambrige University Press.

Chen, J. V., Jubilado, R. J. M., Capistrano, E. P. S., \& Yen, D. C. (2015). Factors affecting online tax filing - An application of the IS success model and trust theory. Computers in Human Behavior, 43, 251-262.

Davis, F., Bagozzi, R., \& Warshaw, P. (1989). User acceptance of computer technology: A comparison of two theoretical models. Management Science, 35(8), 982.

Davis, F. D. (1986). A Technology Acceptance Model For Empirically Testing New End-User Information Systems: Theory And Results. PhDThesis - Massachussetts Institute of technology. https://doi.org/10.1016/S0378-7206(01)00143-4

Deakins, E., \& Dillon, S. M. (2002). E-government in New Zealand: The local authority perspective. International Journal of Public Sector Management. https://doi.org/10.1108/09513550210435728

DeLone, W. H., \& McLean, E. R. (1992). Information Systems Success The Quest for the dependent variabel. Infomation System Research, 3(1), 60-95.

DeLone, W. H., \& McLean, E. R. (2003). The DeLone and McLean model of information systems success: A ten-year update. Journal of Management Information Systems, 19(4), 9-30. https://doi.org/10.1080/07421222.2003.11045748

Doll, W. J., \& Torkzadeh, G. (1988). The measurement of end-user computing satisfaction. MIS Quarterly: Management Information Systems. https://doi.org/10.2307/248851

Emawati, I. A. A., Suprasto, H. B., \& Putri, A. D. (2019). Measurement of Regional Financial Management Information Systems Success in Denpasar City Government. International Journal of Sciences: Basic and Applied Research (IJSBAR), 
$46(1), 57-72$.

Goodhue, B. D. L., South, A., \& Thompson, R. L. (1995). Task-Technology Fit and Individual Performance, (June).

Grimmelikhuijsen, S., Porumbescu, G., Hong, B., \& Im, T. (2013). The effect of transparency on trust in government: A crossnational comparative experiment. Public Administration Review, 73(4), 575-586.

Halawi, L. A., McCarthy, R. V., \& Aronson, J. E. (2008). An empirical investigation of knowledge management systems' success. Journal of Computer Information Systems, 48(2), 121-135.

Hou, C.-K. (2012). Examining the effect of user satisfaction on system usage and individual performance with business intelligence systems: An empirical study of Taiwan's electronics industry. International Journal of Information Management, 32(6), 560-573. https://doi.org/10.1016/j.ijinfomgt.2012.03.001

Iivari, J. (2005). An empirical test of the DeLone-McLean model of information system success. ACM SIGMIS Database: the DATABASE for Advances in Information Systems, 36(2), 8-27.

Iranto, B. D. (2012). Pengaruh Kepuasan Pengguna Sistem Informasi Terhadap Kinerja Individu. Fakultas Ekonomi.

Istianingsih, \& Utami, W. (2009). Pengaruh Kepuasan Pengguna Sistem Informasi Terhadap Kinerja Individu (Studi Empiris Pada Pengguna Paket Program Aplikasi Sistem Informasi Akuntansi Di Indonesia). Seminar Nasional Akuntansi XII.

Kementrian Keuangan Republik Indonesia. (2017). Buku Pintar Dana Desa. Buku Pintar Dana Desa. Retrieved from https:/www.kemenkeu.go.id/media/6749/buku-pintar-dana-desa.pdf

Kodarisman, R., \& Nugroho, E. (2013). Evaluasi Penerapan Sistem Informasi Manajemen Kepegawaian ( SIMPEG ) di Pemerintah Kota Bogor. JNTETI ISSN:2301-4156.

Kofahe, M. K., Hassan, H., \& Mohamad, R. (2019). Factors Affecting Successful Implementation of Government Financial Management Information System (Gfmis) in Jordan Public Sector: a Proposed Framework, 32-44. Retrieved from www.ijafb.com

Krisbiantoro, D., Suyanto, M., \& Taufiqluthfi, E. (2015). Evaluasi Keberhasilan Implementasi Sistem Informasi Dengan Pendekatan Hot Fit Model ( Studi Kasus : Perpustakaan STMIK AMIKOM Purwokerto ). Konferensi Nasional Sistem \& Informatika.

Kristiansen, S., Dwiyanto, A., Pramusinto, A., \& Putranto, E. A. (2009). Public Sector Reforms and Financial Transparency: Experiences from Indonesian Districts. Contemporary Southeast Asia. https://doi.org/10.1355/cs31-1c

Latifah, N., Widayani, A., \& Normawati, R. A. (2020). Pengaruh Perceived Usefulness Dan Trust Terhadap Kepuasan Konsumen Pada E- Commerce Shopee. Bisma: Jurnal Bisnis Dan Manajemen.

Manoharan, A. P., \& Ingrams, A. (2018). Conceptualizing E-Government from Local Government Perspectives. State and Local Government Review, 50(1), 56-66. https://doi.org/10.1177/0160323x18763964

Mayer, R. C., Davis, J. H., \& Schoorman, F. D. (1995). An Integration Model of Organization Trust. The Academy of Management Review, 20(3), 709-734.

McGill, T., Hobbs, V., \& Klobas, J. (2003). User-developed applications and information systems success: A test of DeLone and McLean's model. Information Resources Management Journal. https://doi.org/10.4018/irmj.2003010103

Mohammadi, H. (2015). Investigating Users' Perspectives on e-learning: An Integration of TAM and IS Success Model. Computers in Human Behavior, 45, 359-374. https://doi.org/10.1016/j.chb.2014.07.044

Muharor, L. A., Busaini, B., \& Fitriah, N. (2016). Determinan Kesuksesan Aplikasi Sia Komdanas Pada Satuan Kerja Di Koordinator Wilayah Pengadilan Tinggi Mataram. InFestasi. https://doi.org/10.21107/infestasi.v11i2.1129

Nam, T. (2018). Examining the Anti-Corruption Effect of e-Government and the Moderating Effect of National Culture: A Cross-Country Study. Government Information Quarterly, 35(2), 273-282. https://doi.org/10.1016/j.giq.2018.01.005

Navarro-Galera, A., Alcaraz-Quiles, F. J., \& Ortiz-Rodríguez, D. (2016). Online Dissemination of Information on Sustainability in Regional Governments: Effects of Technological Factors. Government Information Quarterly, 33(1), 53-66. https://doi.org/10.1016/j.giq.2015.12.003

Noviyanti, N. (2017). MENGUKUR KESUKSESAN SISTEM AKUNTANSI INSTANSI BASIS AKRUAL (SAIBA) MENGGUNAKAN MODEL DeLONE \& McLEAN. Jurnal Tata Kelola \& Akuntabilitas Keuangan Negara. https://doi.org/10.28986/jtaken.v2i2.62

Paquette, S., Jaeger, P. T., \& Wilson, S. C. (2010). Identifying the Security Risks Associated with Governmental Use of Cloud Computing. Government Information Quarterly, 27(3), 245-253. https://doi.org/10.1016/j.giq.2010.01.002

Petter, S., Delone, W., \& McLean, E. R. (2013). Information Systems Success: The Quest for the Independent Variables. Journal of Management Information Systems, 29(4), 7-62. https://doi.org/10.2753/MIS0742-1222290401

Porumbescu, G. A. (2016). Placing the Effect? Gleaning Insights into the Relationship between Citizens' Use of E-Government and Trust in Government. Public Management Review, 18(10), 1504-1535.

PP No.11. Peraturan Pemerintah Republik Indonesia Nomor 11 Tahun 2019 Tentang Perubahan Kedua Atas Peraturan Pemerintah Nomor 43 Tahun 2014 Tentang Peraturan Pelaksanaan Undang-Undang Nomor 6 Tahun 2014 Tentang Desa, Republik Indonesia $§(2019)$.

Purwanto, A. (2007). Rancangan dan implementasi model pemeriksaan kinerja Badan Pemeriksa Keuangan Republik Indonesia atas aplikasi e-government di pemerintah daerah: Electronic Theses \& Dissertations Repository UGM.

Putrawan, N. A., Putri, I. G. A. M. A. D., \& Ariyanto, D. (2017). Analisis Efektivitas Sistem Informasi Manajemen Daerah (SIMDA) Pemerintah Kabupaten Gianyar. E-Jurnal Ekonomi Dan Bisnis Universitas Udayana. 
Rahyuda, I. K., Purbawangsa, I. B. A., \& Surya, I. B. K. (2019). Relationship Between Competitive SMEs' Orientation and "Catur Paramitha." International Journal of Social Economics, 46(7), 861-873.

Rai, A., Lang, S. S., \& Welker, R. B. (2002). Assessing the validity of IS success models: An empirical test and theoretical analysis. Information Systems Research. https://doi.org/10.1287/Isre.13.1.50.96

Rakhmawati, S., \& Isharijadi, I. (2013). Pengaruh Kepercayaan, Persepsi Kegunaan, Persepsi Kemudahan, Dan Persepsi Kenyamanan Terhadap Minat Penggunaan Sistem Internet Banking Pada Nasabah Bank Muamalat Cabang Pembantu Madiun. Assets: Jurnal Akuntansi Dan Pendidikan. https://doi.org/10.25273/jap.v2i2.1200

Rimawati, Y. (2012a). Keberhasilan Implementasi Elektronic Goverment Berdasarkan Persepsi Pengguna. Jurnal Akuntansi Multiparadigma, 3(2), 316-331.

Rimawati, Y. (2012b). Keberhasilan Implementasi Elektronik Government Berdasarkan Persepsi Pengguna. Jurnal AkuntansiMultiparadigma. https://doi.org/10.18202/jamal.2012.08.7164

Saputro, B. D., \& Sukirno, S. (2013). Pengaruh Persepsi Kemudahan Penggunaan, Kepercayaan, Kecemasan Berkomputer Dan Kualitas Layanan Terhadap Minat Menggunakan Internet Banking. Nominal, Barometer Riset AkuntansiDanManajemen. https://doi.org/10.21831/nominal.v2i1.1647

Seddon, P.B. (1997). A Respecification and Extension of the DeLone and McLean Model of IS Success. Infomation System Research, 8(3), 240-253.

Seddon, P., \& Kiew, M.-Y. (1996). A Partial Test and Development of Delone and Mclean's Model of IS Success. Australasian Journal of Information Systems. https://doi.org/10.3127/ajis.v4i1.379

Seta, H. B., Wati, T., Muliawati, A., \& Hidayanto, A. N. (2018). E-learning Success Model: An Extention of Delone \& Mclean is' Success Model. Indonesian Journal of Electrical Engineering and Informatics, 6(3), 281-291.

Setyo, D., \& Rahmawati, D. A. (2015). Pengaruh kualitas sistem dan kualitas informasi terhadap kepuasan pengguna. Jurnal Bisnis Dan Ekonomi. https://doi.org/10.1017/CBO9781107415324.004

Srivastava, S. C., \& Teo, T. S. H. (2005). Citizen trust development for e-Government adoption: Case of Singapore. In 9th Pacific Asia Conference on Information Systems: I.T. and Value Creation, PACIS 2005.

Sugiyono. (2017). Metode Penelitian Bisnis (Pendekatan Kuantitatif, Kualitatif, Kombinasi dan R\&D). In Metodelogi Penelitian.

Sumiyana, \& Pribadi, A. (2010). Pemrediksian Peningkatan Manfaat Penggunaan Situs Pajak: Model Kesuksesan Sistem dengan Pengindusian Orientasi Tujuan Pembelajaran dan Norma Subyektif. Universitas Gadjah Mada.

Susanty, M. (2013). Pengujian Model DeLone Dan McLean dalam Pengembangan Sistem IFCA. JURNAL BISNIS DAN AKUNTANSI, 15(2), 142-150.

Tan, D., Suyatno, \& Aliyah, S. (2015). Pengujian Kesuksesan Sistem Informasi Model Delone \& Mclean Pada Sektor Publik. University Research Colluqoium, 111-122.

Teo, T. S. H., Srivastava, S. C., \& Jiang, L. (2008). Trust and electronic government success: An empirical study. Journal of Management Information Systems, 25(3), 99-132. https://doi.org/10.2753/MIS0742-1222250303

Turner, G. B., Taylor, G. S., \& Hartley, M. F. (1995). Ethics, gratuities, and professionalization of the purchasing function. Journal of Business Ethics. https://doi.org/10.1007/BF00872328

UU No.6. (2014). UNDANG-UNDANG REPUBLIK INDONESIA NOMOR 6 TAHUN 2014 TENTANG DESA. https://doi.org/10.1145/2904081.2904088

Venkatesh, V., Morris, M. G., Davis, G. B., \& Davis, F. D. (2003). User acceptance of information technology: Toward a unified view. MIS Quarterly: Management Information Systems. https://doi.org/10.2307/30036540

Wahyuni, T. (2011). Uji empiris model delone dan mclean terhadap kesuksesan sistem informasi manajemen daerah (simda). Jurnal BPPK.

Wang, W., \& Benbasat, I. (2008). Attributions of Trust in Decision Support Technologies: A Study of Recommendation Agents for e-Commerce. Journal of Management Information Systems, 24(4), 249-273.

Wartini, N. N., \& Yasa, I. G. W. M. (2016). Analisis Efektivitas Sistem Informasi Keuangan Daerah (SIKD) Pemerintah Kabupaten Jembrana. E-Jurnal Ekonomi Dan Bisnis Universitas.

Widagdo, A. K., Widodo, A., \& Ismail, M. (2016). Sistem Akuntansi Pengelolaan Dana Desa. Jurnal Ekonomi Dan Bisnis. https://doi.org/10.24914/jeb.v19i2.336

Xiao, L., Fu, B., \& Liu, W. (2018). Understanding Consumer Repurchase Intention on O2O Platforms: an Integrated Model of Network Externalities and Trust Transfer Theory. Service Business, 12(4), 731-756.

Yuhelson, Ariyanto, D., Ernawati, Soejono, F., \& Dewi, S. P. (2020). Digital economy and financial inclusion. Journal of Environmental Treatment Techniques, 8(1), 241-243.

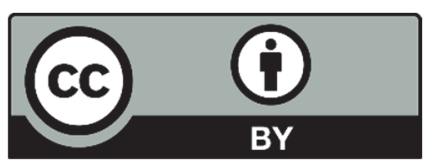

(C) 2020 by the authors; licensee Growing Science, Canada. This is an open access article distributed under the terms and conditions of the Creative Commons Attribution (CC-BY) license (http://creativecommons.org/licenses/by/4.0/). 